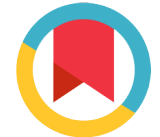

Check for updates $\uparrow$ The authors consider that the first two authors should be regarded as joint first authors

* For correspondence:

amraei.mansour@yahoo.com

Competing interests: The authors declare that no competing interests exist.

Received: 17 January 2018

Accepted: 13 March 2018

Published: 19 March 2018

Copyright The Author(s) 2018. This article is published with open access by BioMedPress

This article is distributed under the terms of the Creative Commons Attribution License (CC-BY 4.0) which permits any use, distribution, and reproduction in any medium, provided the original author(s) and the source are credited.

\section{A systematic review and meta-analysis of the association between vitamin D deficiency and gestational diabetes mellitus}

\section{Shahin Nargesi ${ }^{1}, \dagger$, Ayub Ghorbani2,t, Ehsan Shirzadpour ${ }^{3}$, Mahmoud Mohamadpour ${ }^{3}$, Seyedeh Fatemeh Mousavi ${ }^{4}$, Mansour Amraei ${ }^{2, *}$}

\author{
1Department of Public Health, Faculty of Health, Ilam University of Medical Sciences, \\ Ilam \\ 2Department of Physiology, Faculty of Medicine, Ilam University of Medical Sciences, \\ llam \\ ${ }^{3}$ Department of Biochemistry, Faculty of Medicine, Ilam University of Medical Sciences, \\ llam \\ 4Student Research committee, Ilam University of Medical Sciences, Ilam
}

\section{Abstract}

Introduction: Vitamin D deficiency has become quite prevalent and is known to cause a great many diseases. Numerous studies have investigated the association between vitamin $\mathrm{D}$ deficiency and gestational diabetes, and the results are somewhat contradictory. The present study deals with the relationship between the vitamin D deficiency and gestational diabetes. Methods: Two researchers made use of MeSH, Scopus, PubMed database, Science Direct, the Cochrane Library, the Web of Science, CINAHL, and Google Scholar search engines to identify qualified studies and articles carried out and published before August 2017 and reported the risk of gestational diabetes developing as a result of vitamin D deficiency. The association between the two conditions was measured using odds ratios (ORs) with $95 \%$ confidence intervals (Cls). Funnel plots, Egger's, and Begg's tests were also used to assess publication bias. All analysis was done by STATA (version 11.2). Results: Twenty-nine eligible studies with a total of 14,497 participants were included in the final analysis. Overall, maternal vitamin D insufficiency was significantly associated with a greater risk of gestational diabetes $(O R=1.15 ; 95 \% \mathrm{Cl}$, 1.00-1.30; $p<0.001)$. Serum 25OHD was significantly lower in participants with gestational diabetes mellitus than in those with natural glucose tolerance $(-29.7 \mathrm{nmol} / \mathrm{L}, 95 \% \mathrm{Cl},-36.6$ to $-22.8 ; \mathrm{p}=0.000)$. 
Conclusion: According to the current meta-analysis results, vitamin D deficiency is correlated with the risk of gestational diabetes development.

\section{Keywords}

Gestational Diabetes, Meta-Analysis, Pregnancy, Vitamin D

\section{Introduction}

Vitamin D deficiency is a costly health problem worldwide, and about one billion individuals in the world suffer from it (Holick, 2010). Vitamin D is necessary agent for the regulation of mineral metabolism and skeletal health. Therefore, it plays a significant role in the health, growth, and fertility of humans (Brown et al., 1999; Hagenau et al., 2009).

Vitamin $\mathrm{D}$ deficiency during pregnancy can be accompanied by numerous maternal and fetal symptoms, including, inter alia, insulin resistance, gestational diabetes mellitus (GDM), increased risk of preeclampsia, bacterial vaginitis, and increased rate of cesareans among mothers and autism, Type I diabetes, increased rate of fetal growth delay, increased rate of respiratory infection, low birth weight, increased rate of HIV transmission from mother to fetus, asthma, and eczema in infants (Aghajafari et al., 2013; Palacios et al., 2016). The effect of vitamin D deficiency on the emergence of certain chronic diseases like autoimmune diseases (Arnson et al., 2007), systemic lupus erythematosus (SLE) (Amital et al., 2010), multiple sclerosis (MS) (Ascherio et al., 2010), and malignancies (Trump et al., 2010) has also been recognized.

A poor vitamin D status has been proposed as one risk factor associated with the incidence of GDM. The need for vitamin D is higher in some stages of life, including the period of rapid growth for fetuses in the embryonic stage, infancy, early stages of childhood, puberty, and pregnancy (Shahgheibi et al., 2016). Vitamin D deficiency is common in pregnancy, and it significantly increases the risk for preeclampsia, cesarean section (C/S), and GDM in pregnancies (Gernand et al., 2014; Grant et al., 2014; Merewood et al., 2009; Robinson et al., 2010; Yap et al., 2014).

Recent evidence suggests that vitamin D receptors are expressed in a large number of other tissues, including those involved in the regulation of glucose metabolism such as muscle and pancreatic beta cells (Jain et al., 2015). These receptors have a direct effect on pancreatic beta cells and are required for the normal production and secretion of insulin by the endocrine pancreas (Kramer et al., 2014; Maghbooli et al., 2008). Thus, vitamin D deficiency is related to alterations in blood glucose and insulin concentrations and in target tissue sensitivity to insulin (Shahgheibi et al., 2016). Vitamin D replenishment restores 
insulin secretion and sensitivity in patients with Type 2 diabetes with established vitamin D deficiency (Muthukrishnan and Dhruv, 2015). Therefore, it was hypothesized that GDM might result from pregnancy-induced insulin resistance and impaired secretion to compensate for it.

There has been a rapidly growing interest in the association between vitamin $D$ and the risk of gestational diabetes mellitus, and many studies with various populations and outcomes have been conducted on this topic. It is very important to have an overall estimation of its association. Also, understanding the breadth and quality of the conducted studies is critical. Recently some meta-analyses have found that vitamin $D$ insufficiency is associated with increased GDM risk (Aghajafari et al., 2013; Lu et al., 2016; Poel et al., 2012; Zhang et al., 2015). Despite these findings, the knowledge and understanding of the clinical importance and implications of this association are limited. Moreover, since the publication of these meta-analyses, additional studies on this topic have been published. These studies have other clinically important outcomes that have not yet been effectively summarized. In order to authenticate these studies, an updated meta-analysis seems to be imperative. Thus, the current study aimed to quantitatively evaluate the association between vitamin $\mathrm{D}$ status and risk of gestational diabetes.

\section{Materials-Methods}

\section{Search Method}

The present review study was conducted based on systematic article review protocol and meta-analysis (PRISMA) (Moher et al., 2009). To prevent the occurrence of any error or mistake during the search phase of the study, a quality evaluation and data extraction were carried out by two independent researchers. The compliance between the results and the discrepancies of the findings, if any, were investigated by a third researcher. To identify relevant studies, two independent researchers performed an internet-based search of such databases as PubMed, Scopus, Science Direct, the Cochrane Library, the Web of Science, $\mathrm{CINAHL}$, and Google Scholar search engines with the exertion of no time limitation until August 2017. Subsequently, the references cited in the articles were investigated to access other related studies. To perform searches in the relevant databases, the researchers used $\mathrm{MeSH}$-equivalent keywords, including "vitamin D", "25, 1-dehydroxy cholecalciferol", "25-hydroxy Vitamin $\mathrm{D}$ ", and"25(OH)D" along with "gestational diabetes". The meta-analyses were limited to studies published in English.

\section{Inclusion and exclusion criteria}


To do further research, the abstracts and titles were studied by two arbiters. In order for screening studies to be included in the current meta-analysis, they had to have examined the relationship between vitamin $D$ and the risk of developing gestational diabetes; have studied healthy pregnant women or pregnant women diagnosed with no chronic symptoms; have made use of blood samples for laboratory tests; and have compared women with gestational diabetes with women featuring natural glucose tolerance (NGT). Studies done on pregnant women with chronic illness were out of the scope of the current study. Studies implemented on non-human creatures (i.e. animal studies), those in languages other than English, those that were meta-analyses or systematic considerations as well as those that presented insufficient data or were duplicate publications were also excluded.

Study quality was evaluated using the STROBE (strengthening the reporting of observational studies in epidemiology) statement (von Elm et al., 2008) and assessed based on variables related to the study objectives, characteristics of the study population, clearly explained inclusion/exclusion criteria, and the data collection method as well as the validity, explicit findings, and appropriate data analysis methods of the studies. Non-qualified studies were excluded.

\section{Data extraction}

Data was extracted from qualifying papers according to standard protocol. The data collected included the name of the first author, country, publication year, sample size, age groups, current status, study design, assessment of vitamin $D$ levels, and the effect estimate with $95 \% \mathrm{Cl}$. When necessary, the authors of articles were contacted for supplementary data or clarification. Information was extracted from the authors by two reviewers working independently, and their findings were compared afterwards. Disagreements on the eligibility of a study were resolved through group discussion. The data was entered into a standardized data extraction form and eventually into Microsoft Excel.

\section{Data synthesis and analysis}

The effect estimates ( $R R$ and $O R$ ) reported with $95 \% \mathrm{Cl}$ were used as the measure of association between vitamin $D$ status and the risk of GDM. To account for the variance in the ways in which and degrees to which studies control for potential confounding factors, the risk estimates were maximally adjusted for potential confounders. The statistical heterogeneity between studies was evaluated using Cochran's $\mathrm{Q}$ and $\mathrm{I}^{2}$ statistics. Wherever the results of studies were heterogeneous, a random effects model was used in the metaanalysis. A subgroup analysis was carried out in search for possible causes of the heterogeneity. The pooled estimates and corresponding $95 \%$ confidence intervals were visually assessed with the use of Forest plots. To investigate the influence of each study on the overall risk estimate, a sensitivity analysis was performed by removing individual studies in turn. Publication bias was assessed 
qualitatively using Funnel plots, Egger's regression, and the Begg-Mazumdar rank correlation tests.

Values of $p<0.05$ were considered to denote significance in the heterogeneity tests. Statistical analyses were carried out in the software applications $\mathrm{R}$ (version 3.2.1) and STATA (version 11.1). All statistical tests were two-sided.

\section{Results}

In the initial electronic search, a total of 278 potential articles were identified. A hand search of the bibliographies and reference lists of these articles identified 14 additional articles for a total of 292 articles identified through the literature search. After the initial screening of abstracts and titles, 224 papers were excluded based on the inclusion criteria, leaving 68 papers for a full text review. In a secondary screening and after the full text reviews, another 39 articles were excluded (four studies not in a pregnant population, eight studies in pregnant women with chronic disease, six studies for non-blood sampling, three studies for biological mechanisms, four studies for no outcome data, six studies for insufficient data, two studies for non-humans, and one study that was not in English). In total, 29 studies were selected for the final analysis (Fig. 1).

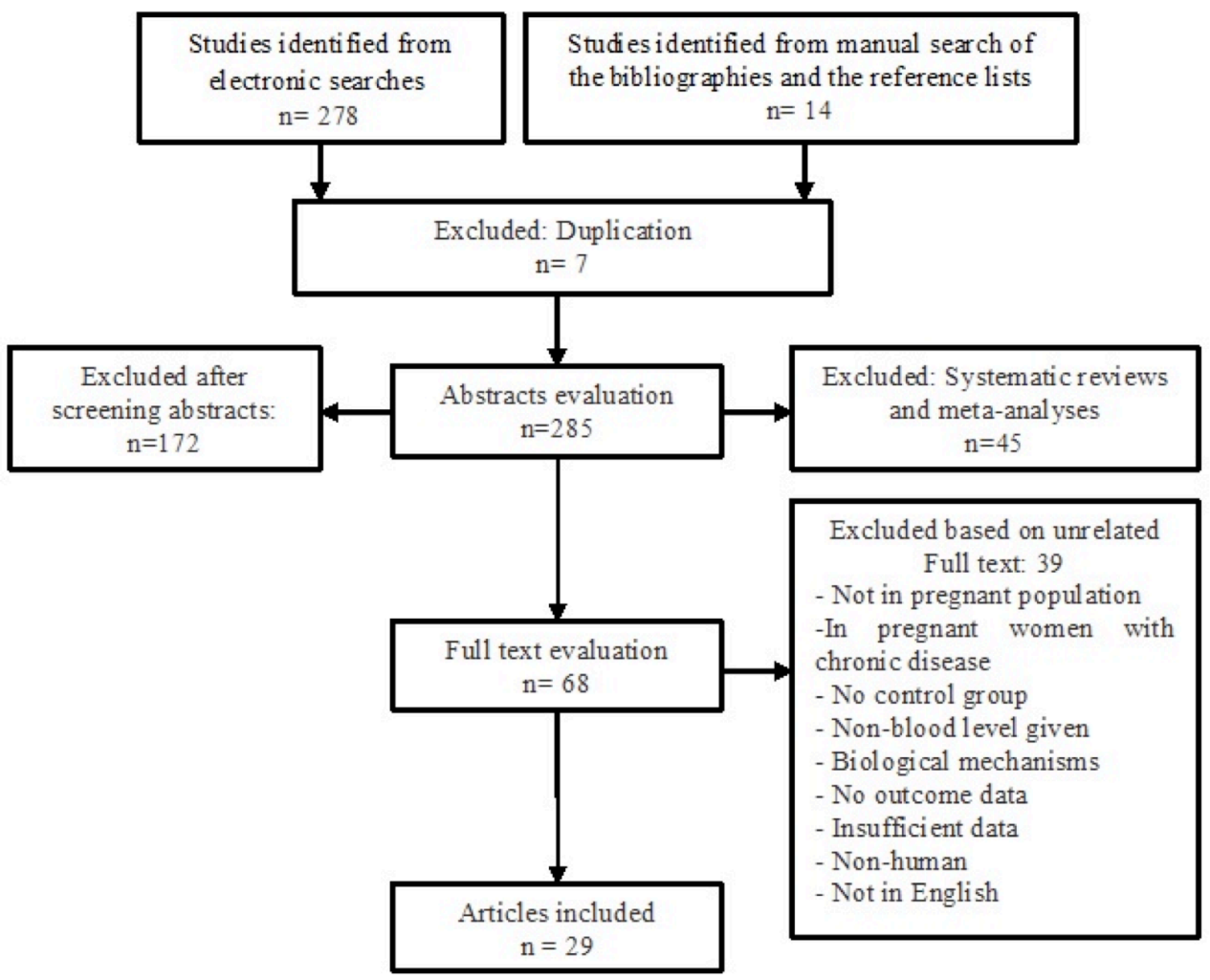

Figure 1. Flow chart of study entry into process. 


\section{Description of the Studies}

As seen in Table 1, all 29 articles presented their findings as proportions. The studies used in this meta-analysis were published between 2008-2016 (Table 1).

Table 1. Characteristics of studies entered into this meta-analysis

\begin{tabular}{|c|c|c|c|c|c|c|c|c|c|}
\hline \multirow{2}{*}{$\begin{array}{l}\text { Study } \\
\text { [reference] }\end{array}$} & \multirow{2}{*}{ Country } & \multirow{2}{*}{$\begin{array}{l}\text { Study } \\
\text { design }\end{array}$} & \multicolumn{2}{|c|}{$\begin{array}{l}\text { Sample size } \\
\text { (n) }\end{array}$} & \multirow{2}{*}{$\begin{array}{c}\text { Age at } \\
\text { Baseline } \\
\text { (Year) }\end{array}$} & \multirow{2}{*}{$\begin{array}{l}\text { Current } \\
\text { status }\end{array}$} & \multicolumn{2}{|c|}{$\begin{array}{c}\text { Mean 25(OH)D nmol/L } \\
\text { (SD) }\end{array}$} & \multirow{2}{*}{ Significant } \\
\hline & & & GDM & NGT & & & GDM & NGT & \\
\hline $\begin{array}{l}\text { Shahgheibi et } \\
\text { al., } 2016\end{array}$ & Iran & $\begin{array}{l}\text { Case } \\
\text { control }\end{array}$ & 43 & 44 & 31.28 & $\begin{array}{c}\text { first } \\
\text { trimester }\end{array}$ & $13.5(7.6)$ & $17.4(14.9)$ & Yes \\
\hline $\begin{array}{l}\text { Jain et al., } \\
2015\end{array}$ & India & $\begin{array}{c}\text { Nested } \\
\text { case control }\end{array}$ & 51 & 19 & $<45$ & $\begin{array}{c}<20 \\
\text { weeks }\end{array}$ & $29.64(8.49)$ & $55.3(37.96)$ & Yes \\
\hline $\begin{array}{l}\text { Maghbooli et } \\
\text { al., } 2008\end{array}$ & Iran & $\begin{array}{l}\text { Cross- } \\
\text { sectional }\end{array}$ & 52 & 579 & 25.6 & $\begin{array}{l}24-28 \\
\text { weeks }\end{array}$ & $16.5(10.4)$ & $22.9(18.3)$ & No \\
\hline $\begin{array}{l}\text { Kramer et al., } \\
2014\end{array}$ & Canada & Cohort & 142 & 125 & 34.4 & NR & $N R$ & NR & No \\
\hline $\begin{array}{l}\text { Muthukrishna } \\
\mathrm{n} \text { and Dahruv, } \\
2016\end{array}$ & India & $\begin{array}{l}\text { Case } \\
\text { control }\end{array}$ & 51 & 19 & 26.5 & $\begin{array}{c}<28 \\
\text { weeks }\end{array}$ & $24.7(17.6)$ & $45.8(28)$ & Yes \\
\hline $\begin{array}{l}\text { Clifton-Bligh } \\
\text { et al., } 2008\end{array}$ & Australia & $\begin{array}{l}\text { Cross- } \\
\text { sectional }\end{array}$ & 81 & 226 & 32.6 & $\begin{array}{l}\text { Second or } \\
\text { third } \\
\text { trimester }\end{array}$ & $48.6(24.9)$ & $55.3(23.3)$ & No \\
\hline $\begin{array}{l}\text { Zhang et al., } \\
2008\end{array}$ & US & $\begin{array}{l}\text { Nested } \\
\text { case } \\
\text { control }\end{array}$ & 57 & 114 & 33.5 & $\begin{array}{l}24-28 \\
\text { weeks }\end{array}$ & $60.4(21.22)$ & $75.13(24.21)$ & Yes \\
\hline $\begin{array}{l}\text { Farrant et al., } \\
2009\end{array}$ & India & $\begin{array}{l}\text { Cross- } \\
\text { sectional }\end{array}$ & 39 & 520 & 23.7 & $\begin{array}{c}<32 \\
\text { weeks }\end{array}$ & $49.3(31.2)$ & $46.4(30.9$ & No \\
\hline $\begin{array}{l}\text { Soheilykhah } \\
\text { et al., } 2010\end{array}$ & Iran & $\begin{array}{l}\text { Case } \\
\text { control }\end{array}$ & 54 & 111 & 27.4 & $\begin{array}{l}24-28 \\
\text { weeks }\end{array}$ & $24.01(20.62)$ & $32.2(35.74)$ & No \\
\hline $\begin{array}{l}\text { Makgoba et } \\
\text { al., } 2011\end{array}$ & UK & $\begin{array}{l}\text { Case } \\
\text { control }\end{array}$ & 90 & 158 & 33.5 & $\begin{array}{l}\text { First } \\
\text { trimester }\end{array}$ & $47.2(26.7)$ & $47.6(26.7)$ & No \\
\hline $\begin{array}{l}\text { Savvidou et } \\
\text { al., } 2011\end{array}$ & UK & $\begin{array}{l}\text { Case } \\
\text { control }\end{array}$ & 100 & 1000 & 31.7 & $\begin{array}{l}11-19 \\
\text { weeks }\end{array}$ & NR & NR & No \\
\hline $\begin{array}{l}\text { Baker et al., } \\
2012\end{array}$ & US & $\begin{array}{c}\text { Nested- } \\
\text { case-control }\end{array}$ & 60 & 120 & 33.7 & $\begin{array}{l}24-28 \\
\text { weeks }\end{array}$ & $97.0(29.0)$ & $86.0(22.0)$ & No \\
\hline $\begin{array}{l}\text { Parlea et al., } \\
2012\end{array}$ & Canada & $\begin{array}{c}\text { Nested- } \\
\text { case-control }\end{array}$ & 116 & 218 & 34.3 & $\begin{array}{l}15-18 \\
\text { weeks }\end{array}$ & $56.3(19.4)$ & $62.0(21.6)$ & No \\
\hline $\begin{array}{l}\text { Wang et al., } \\
2012\end{array}$ & China & $\begin{array}{c}\text { Nested- } \\
\text { case-control }\end{array}$ & 200 & 200 & 32 & $\begin{array}{l}26-28 \\
\text { weeks }\end{array}$ & $22.4(10.7)$ & $25.9(12.3)$ & Yes \\
\hline
\end{tabular}




\begin{tabular}{|c|c|c|c|c|c|c|c|c|c|}
\hline $\begin{array}{l}\text { Fernandez- } \\
\text { Alonso et al., } \\
2012\end{array}$ & Spain & $\begin{array}{c}\text { Cross- } \\
\text { sectional }\end{array}$ & 36 & 466 & NR & $\begin{array}{l}11-14 \\
\text { weeks }\end{array}$ & NR & NR & No \\
\hline $\begin{array}{l}\text { Perez-Ferre et } \\
\text { al., } 2012\end{array}$ & Spain & $\begin{array}{c}\text { Cross- } \\
\text { sectional }\end{array}$ & 49 & 266 & NR & $\begin{array}{l}24-28 \\
\text { weeks }\end{array}$ & NR & NR & No \\
\hline $\begin{array}{l}\text { Burris et al., } \\
2012\end{array}$ & US & $\begin{array}{l}\text { Cross- } \\
\text { sectional }\end{array}$ & 68 & $\begin{array}{c}1,26 \\
4\end{array}$ & 32 & $\begin{array}{l}26-28 \\
\text { weeks }\end{array}$ & NR & NR & No \\
\hline $\begin{array}{l}\text { Zuhur et al., } \\
2013\end{array}$ & Turkey & $\begin{array}{c}\text { Cross- } \\
\text { sectional }\end{array}$ & 234 & 168 & 30.8 & $\begin{array}{l}24-28 \\
\text { weeks }\end{array}$ & $30.8(16.3)$ & $36.0(16.2)$ & Yes \\
\hline $\begin{array}{l}\text { Bener et al., } \\
2013\end{array}$ & Qatari & Cohort & 260 & $\begin{array}{c}1,61 \\
3\end{array}$ & & $\begin{array}{c}>24 \\
\text { weeks }\end{array}$ & NR & NR & Yes \\
\hline $\begin{array}{l}\text { Parildar et al., } \\
2013\end{array}$ & Turkey & $\begin{array}{l}\text { Case- } \\
\text { control }\end{array}$ & 44 & 78 & 26.4 & $\begin{array}{l}24-32 \\
\text { weeks }\end{array}$ & $48.67(23.21)$ & $57.16(24.96)$ & Yes \\
\hline $\begin{array}{l}\text { Cho et al., } \\
2013\end{array}$ & Korea & $\begin{array}{l}\text { Case- } \\
\text { control }\end{array}$ & 20 & 40 & 33.45 & $\begin{array}{l}24-28 \\
\text { weeks }\end{array}$ & $28.95(22.73)$ & $85.78(47.88)$ & Yes \\
\hline $\begin{array}{l}\text { Schneuer et } \\
\text { al., } 2014\end{array}$ & Australia & $\begin{array}{l}\text { Nested } \\
\text { case } \\
\text { control }\end{array}$ & 376 & $\begin{array}{c}3,71 \\
4\end{array}$ & 33.2 & $\begin{array}{c}\text { First } \\
\text { trimester }\end{array}$ & $56.9(26.9)$ & $52.1(22.1)$ & No \\
\hline $\begin{array}{l}\text { Park et al., } \\
2014\end{array}$ & Korea & Cohort & 23 & 500 & 33.7 & $\begin{array}{l}24-28 \\
\text { weeks }\end{array}$ & 49.4(19.4) & $48(24.8)$ & No \\
\hline $\begin{array}{l}\text { McManus et } \\
\text { al., } 2014\end{array}$ & Canada & $\begin{array}{l}\text { Case- } \\
\text { control }\end{array}$ & 36 & 37 & 31.6 & $\begin{array}{l}24-28 \\
\text { weeks }\end{array}$ & $77.3(24.3)$ & $93.2(19.2)$ & Yes \\
\hline $\begin{array}{l}\text { Zhou et al., } \\
2014\end{array}$ & China & Cohort & 2,960 & 100 & 29.7 & $\begin{array}{l}16-20 \\
\text { weeks }\end{array}$ & & & No \\
\hline $\begin{array}{l}\text { Rodriguez et } \\
\text { al., } 2014\end{array}$ & Spain & Cohort & 93 & $\begin{array}{c}2,28 \\
9\end{array}$ & 32 & 13.5 weeks & $28.42(4.39)$ & $28.41(0.96)$ & No \\
\hline $\begin{array}{l}\text { Arnold et al., } \\
2015\end{array}$ & US & $\begin{array}{c}\text { Nested- } \\
\text { case-control }\end{array}$ & 135 & 517 & 33.5 & $\begin{array}{l}18-22 \\
\text { weeks }\end{array}$ & $59.7(23.5)$ & $66.6(22)$ & No \\
\hline $\begin{array}{l}\text { Pleskacova et } \\
\text { al., } 2015\end{array}$ & Czech & $\begin{array}{l}\text { Case- } \\
\text { control }\end{array}$ & 47 & 29 & 33 & $\begin{array}{l}24-30 \\
\text { weeks }\end{array}$ & $28(3.76)$ & $31.85(4.62)$ & No \\
\hline $\begin{array}{l}\text { Lacroix et al., } \\
2014\end{array}$ & Canada & $\begin{array}{l}\text { Cross- } \\
\text { sectional }\end{array}$ & 54 & 601 & 28.4 & $\begin{array}{c}6-13 \\
\text { weeks }\end{array}$ & $57.5(17.2)$ & 63.5(18.9) & No \\
\hline
\end{tabular}

\section{Main Analysis}

Those studies reporting odds ratios were pooled to quantify the association between 25-OHD insufficiency and GDM. Among the 29 studies, only ten showed a significant association between vitamin $D$ status and risk of GDM; nineteen studies reported no significant association between vitamin $D$ status and GDM. However, the present meta-analysis showed that vitamin D insufficiency was associated with increased gestational diabetes risk on a random effects model ( $O R=1.15 ; 95 \% \mathrm{Cl}, 1.00-1.30 ; p<0.001)$ (Fig. 2). Little evidence of heterogeneity was observed among the studies $\left(I^{2}=31.6 \% ; p=0.055\right)$. 


\begin{tabular}{|c|c|c|c|}
\hline \multicolumn{2}{|l|}{$\begin{array}{l}\text { Study } \\
\text { ID }\end{array}$} & \multirow{2}{*}{$\begin{array}{l}\text { OR }(95 \% \mathrm{Cl}) \\
1.92(0.89,4.15)\end{array}$} & \multirow{2}{*}{$\begin{array}{l}\begin{array}{l}\% \\
\text { Weight }\end{array} \\
0.81\end{array}$} \\
\hline Clifton-Bligh (2008) & $\leftarrow$ & & \\
\hline Zhang (2008) & $1 \rightarrow \infty$ & $3.06(1.43,6.57)$ & 0.33 \\
\hline Maghbooli (2008) & $\mid$ & $2.18(0.66,7.20)$ & 0.20 \\
\hline Farrant (2009) & - & $1.01(0.50,2.03)$ & 3.68 \\
\hline Soheilykhah (2010) & + & $2.03(0.89,4.62)$ & 0.62 \\
\hline Makgoba (2011) & $\because$ & $0.80(0.43,2.58)$ & 1.86 \\
\hline Savvidou (2011) & - & $1.35(0.77,2.35)$ & 3.45 \\
\hline Baker (2012) & $1+$ & $1.27(0.40,4.07)$ & 0.64 \\
\hline Parlea (2012) & - & $1.31(0.79,2.19)$ & 4.40 \\
\hline Wang (2012) & - & $1.80(1.21,2.68)$ & 3.99 \\
\hline Fernandez-Alonso (2012) & $1 \div$ & $1.72(0.83,3.56)$ & 1.16 \\
\hline Perez-Ferre (2012) & $\leftarrow$ & $1.01(0.54,1.89)$ & 4.73 \\
\hline Burris (2012) & $\bullet$ & $1.27(0.77,2.11)$ & 4.80 \\
\hline Zuhur (2013) & $1 \leftarrow$ & $1.94(1.13,3.33)$ & 1.78 \\
\hline Bener (2013) & - & $1.34(1.04,1.80)$ & 14.92 \\
\hline Parildar (2013) & $1+\infty$ & $2.35(1.10,5.00)$ & 0.57 \\
\hline Cho (2013) & 1 & $14.94(1.44,30.15)$ & 0.01 \\
\hline Schneuer (2013) & $\leftarrow$ & $1.58(0.85,3.78)$ & 1.00 \\
\hline Lacroix (2014) & 10 & $1.69(0.95,3.03)$ & 1.99 \\
\hline Park (2014) & - & $0.58(0.29,1.75)$ & 4.04 \\
\hline McManus (2014) & $1 !-$ & $5.96(2.23,10.25)$ & 0.13 \\
\hline Zhou (2014) & $\leftarrow$ & $0.68(0.49,1.95)$ & 4.04 \\
\hline Rodrigues (2014) & $\bullet$ & $1.11(0.69,1.77)$ & 7.39 \\
\hline Kramer (2014) & $\bullet$ & $0.85(0.75,1.28)$ & 30.68 \\
\hline Arnold (2015) & $\leftarrow$ & $1.02(0.88,2.88)$ & 2.15 \\
\hline Pleskacova (2015) & 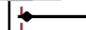 & $1.67(0.82,12.53)$ & 0.06 \\
\hline Jain (2015) & $1-$ & $13.14(3.12,25.00)$ & 0.02 \\
\hline Shahgheibi (2016) & b- & $3.75(1.33,10.22)$ & 0.11 \\
\hline Muthukrishnan (2016) & - & $2.75(1.22,5.66)$ & 0.44 \\
\hline Overall (I-squared $=31.6 \%, p=0.055$ ) & i & $1.15(1.00,1.30)$ & 100.00 \\
\hline 1 & 1 & & \\
\hline
\end{tabular}

Figure 2. Meta-analysis of the association between vitamin $D$ deficiency and risk of gestational diabetes mellitus. Relative risks are shown for the association of vitamin D deficiency with the incidence of GDM. Black squares and horizontal lines represent, respectively, the study-specific odds ratios and the corresponding $95 \% \mathrm{Cl}$. The sizes of the black squares reflect the weights of the respective studies. The diamonds represent pooled odd ratios with $95 \% \mathrm{Cls}$.

A meta-analysis was performed to determine whether there were significant differences between mean vitamin $D$ levels among women with and without GDM. Figure 3 shows the results of a comparison of the mean differences of these studies. Based on a random-effects model meta-analysis, the pooled weighted mean difference was $-29.7 \mathrm{nmol} / \mathrm{L}(95 \% \mathrm{Cl}-36.6$ to -22.8$)$, and significant heterogeneity was observed ( $12=75.7 \%, p=0.000)$ (Fig. 3). These results indicated that pregnant women with GDM in these studies had significantly lower vitamin $D$ levels than the comparison group and further demonstrated that vitamin $D$ deficiency is significantly associated with an increased risk of GDM.

A sensitivity analysis was also conducted to examine the influence of various exclusion criteria on the overall risk estimate. After each study was sequentially excluded from the pooled analysis, the overall combined relative risk did not alter. The exclusion of any single study yielded similar results, and the conclusion was not affected by excluding any specific study. 


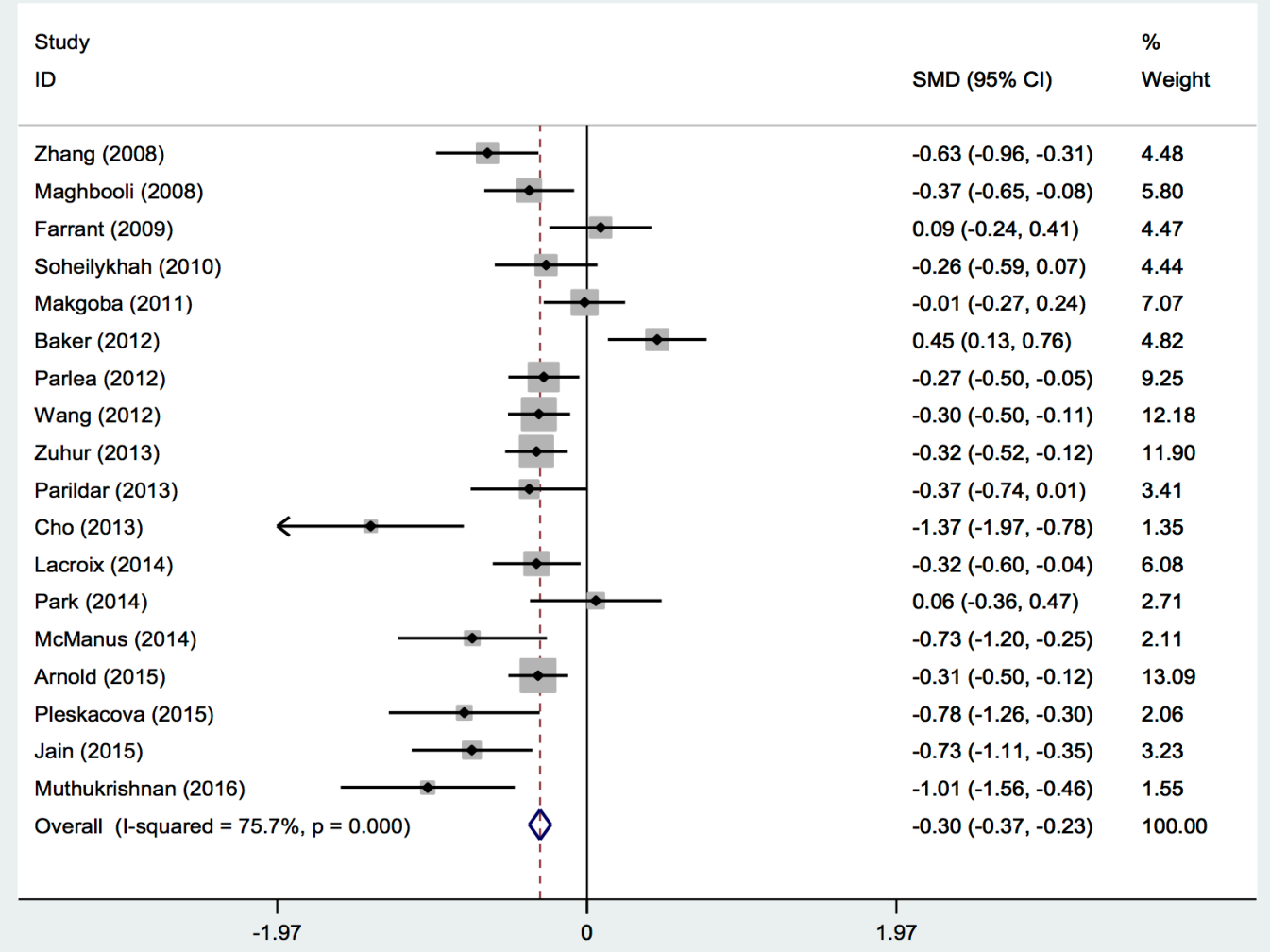

Figure 3. Meta-analysis of the association between serum 25(OH)D level and gestational diabetes mellitus. Differences in means are shown between maternal serum 25(OH)D in pregnant women with GDM and normal glucose tolerance (NGT). The black squares and horizontal lines represent the study specific difference in means and corresponding $95 \% \mathrm{Cl}$, respectively. The sizes of the black squares reflect the weights of the respective studies. The diamonds represent pooled differences in means with $95 \% \mathrm{Cls}$.

We also evaluated the association between vitamin D status and the risk of GDM based on region. Selected studies were conducted in different countries. Of the 29 studies, 2 were conducted in Australia (Clifton-Bligh et al., 2008; Schneuer et al., 2014), eight were conducted in North America (Arnold et al., 2015; Baker et al., 2012; Burris et al., 2012; Kramer et al., 2014; Lacroix et al., 2014; McManus et al., 2014; Parlea et al., 2012; Zhang et al., 2008), eleven were conducted in Asia (Bener et al., 2013; Cho et al., 2013; Farrant et al., 2009; Jain et al., 2015; Maghbooli et al., 2008; Muthukrishnan and Dhruv, 2015; Park et al., 2014; Shahgheibi et al., 2016; Soheilykhah et al., 2010; Wang et al., 2012; Zhou et al., 2014) and the remaining 8 were performed in Europe (Fernandez-Alonso et al., 2012; Makgoba et al., 2011; Parildar et al., 2013; Perez-Ferre et al., 2012; Pleskacova et al., 2015; Rodriguez et al., 2015; Savvidou et al., 2011; Zuhur et al., 2013). The result of our meta analysis showed no significant associations between vitamin $D$ status and GDM risk based on geographic area ( $P$ for heterogeneity [Phet] $=0.171$, Fig. 4). 


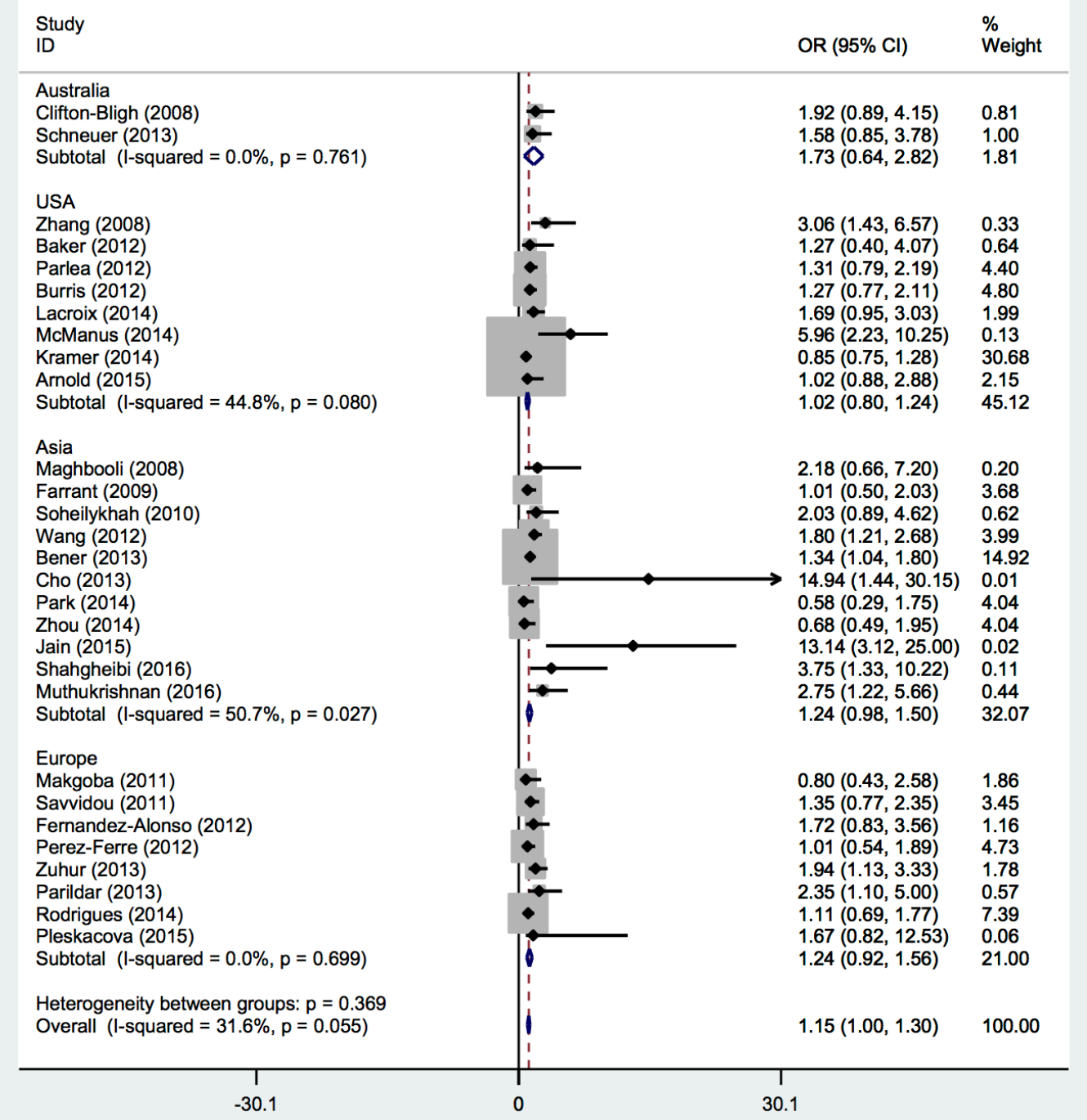

Figure 4. Meta-analysis of the association between serum 25(OH)D level and GDM based on region. Black squares and horizontal lines represent, respectively, the study-specific odds ratios and the corresponding $95 \% \mathrm{Cl}$. The sizes of the black squares reflect the weights of the respective studies. The diamonds represent pooled odd ratios with $95 \% \mathrm{Cls}$.

\section{Publication Bias}

According to the publication bias tests, the effect of bias in these studies was not significant. No sign of publication bias was observed when Begg's funnel plot was examined. Figure 5 presents the Begg's funnel plot of the included trials related to vitamin D deficiency in GDM patients. 


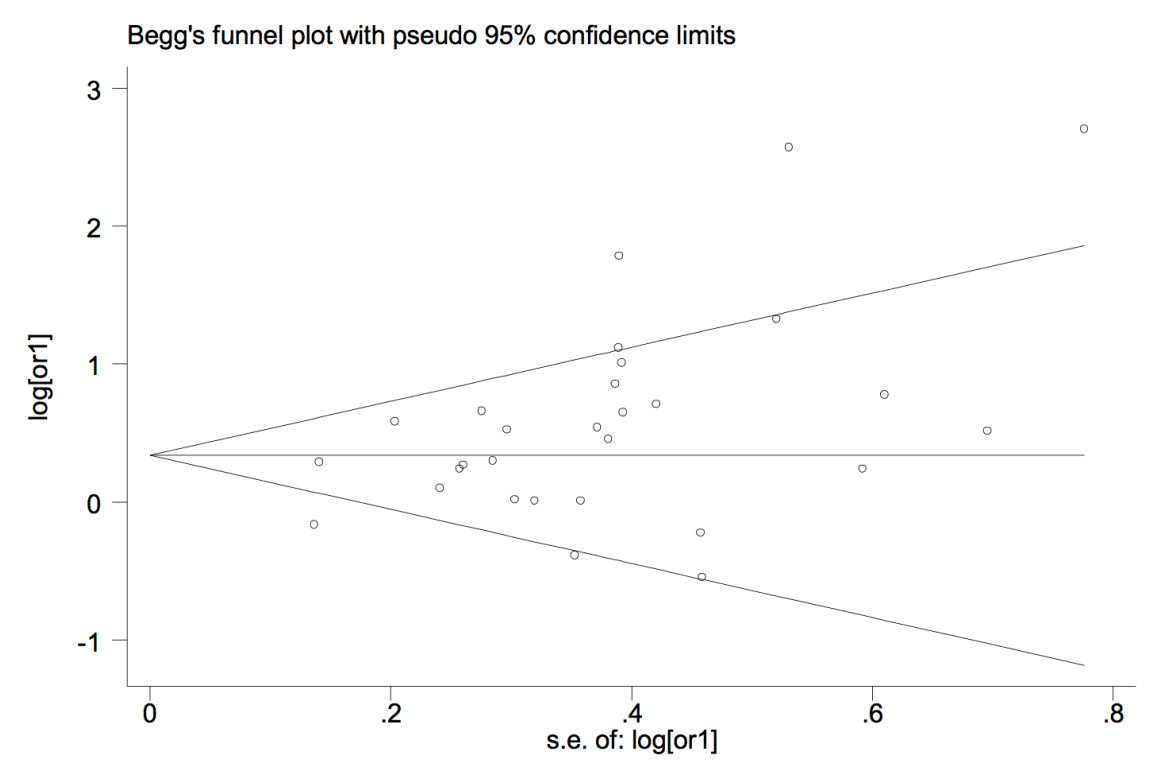

Figure 5. Funnel plot (from Begg-Mazumdar test) for publication bias in the risk difference analysis.

\section{Discussion}

The literature on vitamin $D$ insufficiency in pregnancy is growing rapidly. The current meta-analysis was conducted to comprehensively review the literature and explore possible correlations between vitamin D status and the risk of GDM.

In this systematic review and quantitative meta-analysis of 29 observational studies, an association was found between insufficient vitamin $D$ levels and the incidence of GDM. Women with GDM appear to have a significant lower serum $25 \mathrm{OHD}$ than women with NGT. The current results suggest that vitamin D deficiency may be an independent risk factor for GDM. These results are consistent with those of previous meta-analyses (Aghajafari et al., 2013; Lu et al., 2016; Poel et al., 2012; Zhang et al., 2015). Since the publication of themetaanalyses included in this research, further studies have been published. Moreover, the previous meta-analyses did not include several important observational studies. The current study attempts to fill this gap.

Obesity as well as a high maternal age are risk factors for both vitamin D deficiency and gestational diabetes; thus, they are potential confounders of the association between vitamin D deficiency and the incidence of GDM (Poel et al., 2012). Most of the studies included in the current meta-analysis had been adjusted for maternal age and $\mathrm{BMl}$; however, the association between vitamin $\mathrm{D}$ status and GDM was statistically significant.

Recent evidence has suggested that vitamin D deficiency or insufficiency is more common among pregnant women with limited sun exposure (e.g., those who 
live in cold climates or in northern latitudes) which may affect their vitamin $D$ status; Those women who wear sunscreen or protective clothing and those from ethnic minority groups with darker skin (Bodnar et al., 2007; Hollis and Wagner, 2004; Lee et al., 2007). The majority of vitamin D is generated in the skin under the influence of ultraviolet B radiation, which makes serum 25OHD levels dependent on seasons, with higher levels seen in spring and summer (Poel et al., 2012).

There are also other risk factors that could be associated with GDM risk, including smoking, alcohol intake, gestational weight gain, and socioeconomic status. In the current study, it was observed that the adjusted models differed across the included studies; some of them did not adjust for several important confounding factors. The contribution of these confounding factors to the risk of gestational diabetes can go some distance in explaining conflicting results among different studies.

Other important points noted were that the included studies used different methods and criteria for the diagnosis of GDM, serum 25OHD levels were measured in different trimesters of pregnancy, definitions of cut-offs for 25-OHD insufficiency varied, and different techniques were used. The studies suggest that the methods used to quantify 25-OHD levels and to diagnose GDM may be important factors which could influence the final results (Agarwal et al., 2005; Shirazian et al., 2008).

There were several limitations in the current meta-analysis. First, the included studies varied in their definitions of the cut-off for 25-OHD insufficiency and in diagnostic criteria of GDM, and that could have influenced the pooled effect. Secondly, the researchers were unable to evaluate the impact of some important factors such as gestational weight gain, skin tone, and socioeconomic status on the correlation between maternal vitamin D status and the risk of GDM because of insufficient data in some studies. Also, data on sunlight exposure and dietary vitamin D intake was not available. Thirdly, the most adjusted odds ratio was used in meta-analysis. However, the adjusted models differed across the included studies. In some studies, the potential confounding factors could not be adjusted for, and therefore, the findings could not be pooled by adjusting confounding factors. Furthermore, inherent to any meta-analysis is the possibility of publication bias which is an inevitable problem. Finally, some studies associated with vitamin D status and GDM were not accessible.

\section{Conclusion}

The present meta-analysis indicated that pregnant women with gestational diabetes had significantly lower vitamin $D$ levels than did those with normal glucose tolerance. The results further demonstrated a statistically significant association between maternal vitamin $D$ insufficiency and the incidence of 
gestational diabetes. In conclusion, these findings suggest that low levels of $25(\mathrm{OH}) \mathrm{D}$ may be a risk factor in pregnancy. However, given the variety of study designs and the heterogeneity between the included studies, it is not reasonable to derive a definite conclusion.Further clinical trials are needed to verify this association and determine the explicit effect of vitamin D supplementation on the prevention of gestational diabetes.

\title{
Abbreviations
}

\author{
Cls: Confidence intervals \\ GDM: Gestational Diabetes Mellitus \\ NGT: Natural glucose tolerance \\ NR: Not reported \\ OR: Odds ratios \\ RR: Ratios risk
}

\section{Acknowledgements}

The authors would like to express their gratitude to llam University of Medical Sciences.

\section{Author Contribution}

Shahin Nargesi and Mansour Amraei designed the study and participated in writing the paper, Ayub Ghorbani and Ehsan Shirzadpour performed the meta-analysis, Seyedeh Fatemeh Mousavi, Ehsan Shirzadpour and Mahmoud Mohamadpour participated in writing the paper, Mansour Amraei provided data analysis and participated in writing the paper. All authors read and approved the manuscript.

\section{References}

Agarwal, M. M., Dhatt, G. S., Punnose, J., \& Koster, G. (2005). Gestational diabetes: Dilemma caused by multiple international diagnostic criteria. Diabetic Medicine, 22(12), 1731-1736. https://doi.org/10.1111/j.1464-5491.2005.01706.x PMID: 16401320

Aghajafari, F., Nagulesapillai, T., Ronksley, P. E., Tough, S. C., O'Beirne, M., \& Rabi, D. M. (2013). Association between maternal serum 25-hydroxyvitamin D level and pregnancy and neonatal outcomes: Systematic review and meta-analysis of observational studies. BMJ (Clinical Research Ed.), 346(mar26 4), f1169. https://doi.org/10.1136/bmj.f1169 PMID:23533188

Amital, H., Szekanecz, Z., Szücs, G., Dankó, K., Nagy, E., Csépány, T., . . Shoenfeld, Y. (2010). Serum concentrations of $25-\mathrm{OH}$ vitamin $D$ in patients with systemic lupus erythematosus (SLE) are inversely related to disease activity: Is it time to routinely 
supplement patients with SLE with vitamin D? Annals of the Rheumatic Diseases, 69(6), 1155-1157. https://doi.org/10.1136/ard.2009.120329 PMID:20439290

Arnold, D. L., Enquobahrie, D. A., Qiu, C., Huang, J., Grote, N., VanderStoep, A., \& Williams, M. A. (2015). Early pregnancy maternal vitamin D concentrations and risk of gestational diabetes mellitus. Paediatric and Perinatal Epidemiology, 29(3), 200-210. https://doi.org/10.1111/ppe.12182 PMID:25808081

Arnson, Y., Amital, H., \& Shoenfeld, Y. (2007). Vitamin D and autoimmunity: New aetiological and therapeutic considerations. Annals of the Rheumatic Diseases, 66(9), 1137-1142. https://doi.org/10.1136/ard.2007.069831 PMID:17557889

Ascherio, A., Munger, K. L., \& Simon, K. C. (2010). Vitamin D and multiple sclerosis. Lancet Neurology, 9(6), 599-612. https://doi.org/10.1016/S1474-4422(10)70086-7 PMID:20494325

Baker, A. M., Haeri, S., Camargo, C. A., Jr., Stuebe, A. M., \& Boggess, K. A. (2012). Firsttrimester maternal vitamin $D$ status and risk for gestational diabetes (GDM) a nested case-control study. Diabetes/Metabolism Research and Reviews, 28(2), 164-168. https://doi.org/10.1002/dmrr.1282 PMID:21818838

Bener, A., Al-Hamaq, A. O., \& Saleh, N. M. (2013). Association between vitamin D insufficiency and adverse pregnancy outcome: Global comparisons. International Journal of Women's Health, 5, 523-531. https://doi.org/10.2147/IJWH.S51403 PMID: 24043954

Bodnar, L. M., Simhan, H. N., Powers, R. W., Frank, M. P., Cooperstein, E., \& Roberts, J. M. (2007). High prevalence of vitamin D insufficiency in black and white pregnant women residing in the northern United States and their neonates. The Journal of Nutrition, 137(2), 447-452. https://doi.org/10.1093/jn/137.2.447 PMID:17237325

Brown, A. J., Dusso, A., \& Slatopolsky, E. (1999). Vitamin D. The American Journal of Physiology, 277(2 Pt 2), F157-F175. PMID:10444570

Burris, H. H., Rifas-Shiman, S. L., Kleinman, K., Litonjua, A. A., Huh, S. Y., Rich-Edwards, J. W., . . . Gillman, M. W. (2012). Vitamin D deficiency in pregnancy and gestational diabetes mellitus. American Journal of Obstetrics and Gynecology, 207(3), 182.e1182.e8. https://doi.org/10.1016/j.ajog.2012.05.022 PMID:22717271

Cho, G. J., Hong, S. C., Oh, M. J., \& Kim, H. J. (2013). Vitamin D deficiency in gestational diabetes mellitus and the role of the placenta. American Journal of Obstetrics and Gynecology, 209(6), 560.e1-560.e8. https://doi.org/10.1016/j.ajog.2013.08.015 PMID: 23954530

Clifton-Bligh, R. J., McElduff, P., \& McElduff, A. (2008). Maternal vitamin D deficiency, ethnicity and gestational diabetes. Diabetic Medicine, 25(6), 678-684. https://doi.org/ 10.1111/j.1464-5491.2008.02422.x PMID:18544105

Farrant, H. J., Krishnaveni, G. V., Hill, J. C., Boucher, B. J., Fisher, D. J., Noonan, K., . . Fall, C. H. (2009). Vitamin D insufficiency is common in Indian mothers but is not associated with gestational diabetes or variation in newborn size. European Journal of Clinical Nutrition, 63(5), 646-652. https://doi.org/10.1038/ejcn.2008.14 PMID: 18285809

Fernández-Alonso, A. M., Dionis-Sánchez, E. C., Chedraui, P., González-Salmerón, M. D., \& Pérez-López, F. R., \& the Spanish Vitamin D and Women's Health Research Group. (2012). First-trimester maternal serum 25-hydroxyvitamin $D_{3}$ status and pregnancy outcome. International Journal of Gynaecology and Obstetrics: the Official Organ of the 
International Federation of Gynaecology and Obstetrics, 116(1), 6-9. https://doi.org/ 10.1016/j.ijgo.2011.07.029 PMID:21959069

Gernand, A. D., Simhan, H. N., Caritis, S., \& Bodnar, L. M. (2014). Maternal vitamin D status and small-for-gestational-age offspring in women at high risk for preeclampsia. Obstetrics and Gynecology, 123(1), 40-48. https://doi.org/10.1097/AOG. 0000000000000049 PMID:24463662

Grant, C. C., Stewart, A. W., Scragg, R., Milne, T., Rowden, J., Ekeroma, A., . . Camargo, C. A., Jr. (2014). Vitamin D during pregnancy and infancy and infant serum 25hydroxyvitamin D concentration. Pediatrics, 133(1), e143-e153. https://doi.org/ 10.1542/peds.2013-2602 PMID:24344104

Hagenau, T., Vest, R., Gissel, T. N., Poulsen, C. S., Erlandsen, M., Mosekilde, L., \& Vestergaard, P. (2009). Global vitamin D levels in relation to age, gender, skin pigmentation and latitude: An ecologic meta-regression analysis. Osteoporosis International, 20(1), 133-140. https://doi.org/10.1007/s00198-008-0626-y PMID: $\underline{18458986}$

Holick, M. F. (2010). The vitamin D deficiency pandemic: A forgotten hormone important for health. Public Health Reviews, 32(1), 267-263. https://doi.org/10.1007/ BF03391602

Hollis, B. W., \& Wagner, C. L. (2004). Assessment of dietary vitamin D requirements during pregnancy and lactation. The American Journal of Clinical Nutrition, 79(5), 717726. PMID:15113709

Jain, M., Kapry, S., Jain, S., Singh, S.K., and Singh, T.B. (2015). Maternal Vitamin D Deficiency: A Risk Factor for Gestational Diabetes Mellitus in North India. 5, 264.

Kramer, C. K., Swaminathan, B., Hanley, A. J., Connelly, P. W., Sermer, M., Zinman, B., \& Retnakaran, R. (2014). Vitamin D and parathyroid hormone status in pregnancy: Effect on insulin sensitivity, $\beta$-cell function, and gestational diabetes mellitus. The Journal of Clinical Endocrinology and Metabolism, 99(12), 4506-4513. https://doi.org/10.1210/jc. 2014-2341 PMID:25202819

Lacroix, M., Battista, M. C., Doyon, M., Houde, G., Ménard, J., Ardilouze, J. L., . . Perron, P. (2014). Lower vitamin D levels at first trimester are associated with higher risk of developing gestational diabetes mellitus. Acta Diabetologica, 51(4), 609-616. https:// doi.org/10.1007/s00592-014-0564-4 PMID:24526261

Lee, J. M., Smith, J. R., Philipp, B. L., Chen, T. C., Mathieu, J., \& Holick, M. F. (2007). Vitamin $D$ deficiency in a healthy group of mothers and newborn infants. Clinical Pediatrics, 46(1), 42-44. https://doi.org/10.1177/0009922806289311 PMID:17164508

Lu, M., Xu, Y., Lv, L., \& Zhang, M. (2016). Association between vitamin D status and the risk of gestational diabetes mellitus: A meta-analysis. Archives of Gynecology and Obstetrics, 293(5), 959-966. https://doi.org/10.1007/s00404-016-4010-4 PMID: $\underline{26825733}$

Maghbooli, Z., Hossein-Nezhad, A., Karimi, F., Shafaei, A. R., \& Larijani, B. (2008). Correlation between vitamin D3 deficiency and insulin resistance in pregnancy. Diabetes/Metabolism Research and Reviews, 24(1), 27-32. https://doi.org/10.1002/ dmrr.737 PMID:17607661

Makgoba, M., Nelson, S. M., Savvidou, M., Messow, C. M., Nicolaides, K., \& Sattar, N. (2011). First-trimester circulating 25-hydroxyvitamin D levels and development of gestational diabetes mellitus. Diabetes Care, 34(5), 1091-1093. https://doi.org/ $\underline{10.2337 / \mathrm{dc} 10-2264}$ PMID:21454797 
McManus, R., Summers, K., de Vrijer, B., Cohen, N., Thompson, A., \& Giroux, I. (2014). Maternal, umbilical arterial and umbilical venous 25-hydroxyvitamin $D$ and adipocytokine concentrations in pregnancies with and without gestational diabetes. Horumon To Rinsho, 80(5), 635-641. https://doi.org/10.1111/cen.12325 PMID: $\underline{24102192}$

Merewood, A., Mehta, S. D., Chen, T. C., Bauchner, H., \& Holick, M. F. (2009). Association between vitamin $\mathrm{D}$ deficiency and primary cesarean section. The Journal of Clinical Endocrinology and Metabolism, 94(3), 940-945. https://doi.org/10.1210/jc.2008-1217 PMID:19106272

Moher, D., Liberati, A., Tetzlaff, J., Altman, D. G., \& Group, P., \& the PRISMA Group. (2009). Preferred reporting items for systematic reviews and meta-analyses: The PRISMA statement. PLoS Medicine, 6(7), e1000097. https://doi.org/10.1371/ journal.pmed.1000097 PMID:19621072

Muthukrishnan, J., \& Dhruv, G. (2015). Vitamin D status and gestational diabetes mellitus. Indian Journal of Endocrinology and Metabolism, 19(5), 616-619. https:// doi.org/10.4103/2230-8210.163175 PMID:26425469

Palacios, C., De-Regil, L. M., Lombardo, L. K., \& Peña-Rosas, J. P. (2016). Vitamin D supplementation during pregnancy: Updated meta-analysis on maternal outcomes. The Journal of Steroid Biochemistry and Molecular Biology, 164, 148-155. https:// doi.org/10.1016/j.jsbmb.2016.02.008 PMID:26877200

Parildar, H., Dogruk Unal, A., Aksan Desteli, G., Cigerli, O., \& Guvener Demirag, N. (2013). Frequency of Vitamin D deficiency in pregnant diabetics at Baskent University Hospital, Istanbul. Pakistan Journal of Medical Sciences, 29(1), 15-20. PMID:24353500

Park, S., Yoon, H. K., Ryu, H. M., Han, Y. J., Lee, S. W., Park, B. K., . . Kim, S. H. (2014). Maternal vitamin $D$ deficiency in early pregnancy is not associated with gestational diabetes mellitus development or pregnancy outcomes in Korean pregnant women in a prospective study. Journal of Nutritional Science and Vitaminology, 60(4), 269-275. https://doi.org/10.3177/jnsv.60.269 PMID:25297616

Parlea, L., Bromberg, I. L., Feig, D. S., Vieth, R., Merman, E., \& Lipscombe, L. L. (2012). Association between serum 25-hydroxyvitamin $D$ in early pregnancy and risk of gestational diabetes mellitus. Diabetic Medicine, 29(7), e25-e32. https://doi.org/ 10.1111/j.1464-5491.2011.03550.x PMID:22150870

Perez-Ferre, N., Torrejon, M. J., Fuentes, M., Fernandez, M. D., Ramos, A., Bordiu, E., . . Calle-Pascual, A. L. (2012). Association of low serum 25-hydroxyvitamin D levels in pregnancy with glucose homeostasis and obstetric and newborn outcomes. Endocrine Practice, 18(5), 676-684. https://doi.org/10.4158/EP12025.OR PMID:22548949

Pleskačová, A., Bartáková, V., Pácal, L., Kuricová, K., Bělobrádková, J., Tomandl, J., \& Kaňková, K. (2015). Vitamin D status in women with gestational diabetes mellitus during pregnancy and postpartum. BioMed Research International, 2015, 260624. https:// doi.org/10.1155/2015/260624 PMID:26000285

Poel, Y. H., Hummel, P., Lips, P., Stam, F., van der Ploeg, T., \& Simsek, S. (2012). Vitamin D and gestational diabetes: A systematic review and meta-analysis. European Journal of Internal Medicine, 23(5), 465-469. https://doi.org/10.1016/j.ejim.2012.01.007 PMID: $\underline{22726378}$

Robinson, C. J., Alanis, M. C., Wagner, C. L., Hollis, B. W., \& Johnson, D. D. (2010). Plasma 25-hydroxyvitamin $\mathrm{D}$ levels in early-onset severe preeclampsia. American 
Journal of Obstetrics and Gynecology, 203(4), 366.e1-366.e6. https://doi.org/10.1016/ j.ajog.2010.06.036 PMID:20692641

Rodriguez, A., García-Esteban, R., Basterretxea, M., Lertxundi, A., Rodríguez-Bernal, C., Iñiguez, C., . . Morales, E. (2015). Associations of maternal circulating 25hydroxyvitamin D3 concentration with pregnancy and birth outcomes. BJOG, 122(12), 1695-1704. https://doi.org/10.1111/1471-0528.13074 PMID:25208685

Savvidou, M. D., Akolekar, R., Samaha, R. B., Masconi, A. P., \& Nicolaides, K. H. (2011). Maternal serum 25-hydroxyvitamin $D$ levels at $11(+0)-13(+6)$ weeks in pregnant women with diabetes mellitus and in those with macrosomic neonates. BJOG, 118(8), 951-955. https://doi.org/10.1111/j.1471-0528.2011.02982.x PMID:21658195

Schneuer, F. J., Roberts, C. L., Guilbert, C., Simpson, J. M., Algert, C. S., Khambalia, A. Z., ... Nassar, N. (2014). Effects of maternal serum 25-hydroxyvitamin D concentrations in the first trimester on subsequent pregnancy outcomes in an Australian population. The American Journal of Clinical Nutrition, 99(2), 287-295. https://doi.org/10.3945/ajcn. 113.065672 PMID:24257720

Shahgheibi, S., Farhadifar, F., \& Pouya, B. (2016). The effect of vitamin D supplementation on gestational diabetes in high-risk women: Results from a randomized placebo-controlled trial. Journal of Research in Medical Sciences, 21(1), 2. https://doi.org/10.4103/1735-1995.175148 PMID:27904548

Shirazian, N., Mahboubi, M., Emdadi, R., Yousefi-Nooraie, R., Fazel-Sarjuei, Z., Sedighpour, N., . . Mozaffari-Kermani, R. (2008). Comparison of different diagnostic criteria for gestational diabetes mellitus based on the $75-\mathrm{g}$ oral glucose tolerance test: A cohort study. Endocrine Practice, 14(3), 312-317. https://doi.org/10.4158/EP.14.3.312 PMID:18463038

Soheilykhah, S., Mojibian, M., Rashidi, M., Rahimi-Saghand, S., \& Jafari, F. (2010). Maternal vitamin D status in gestational diabetes mellitus. Nutrition in Clinical Practice, 25(5), 524-527. https://doi.org/10.1177/0884533610379851 PMID:20962313

Trump, D. L., Deeb, K. K., \& Johnson, C. S. (2010). Vitamin D: Considerations in the continued development as an agent for cancer prevention and therapy. Cancer Journal (Sudbury, Mass.), 16(1), 1-9. https://doi.org/10.1097/PPO.0b013e3181c51ee6 PMID: $\underline{20164683}$

von Elm, E., Altman, D. G., Egger, M., Pocock, S. J., Gøtzsche, P. C., \& Vandenbroucke, J. P., \& the Iniciativa STROBE. (2008). [The Strengthening the Reporting of Observational Studies in Epidemiology [STROBE] statement: Guidelines for reporting observational studies]. Gaceta Sanitaria, 22(2), 144-150. https://doi.org/10.1157/13119325 PMID: 18420014

Wang, O., Nie, M., Hu, Y. Y., Zhang, K., Li, W., Ping, F., .. Xing, X. P. (2012). Association between vitamin $D$ insufficiency and the risk for gestational diabetes mellitus in pregnant Chinese women. Biomedical and Environmental Sciences, 25(4), 399-406. PMID:23026519

Yap, C., Cheung, N. W., Gunton, J. E., Athayde, N., Munns, C. F., Duke, A., \& McLean, M. (2014). Vitamin D supplementation and the effects on glucose metabolism during pregnancy: A randomized controlled trial. Diabetes Care, 37(7), 1837-1844. https:// doi.org/10.2337/dc14-0155 PMID:24760259

Zhang, C., Qiu, C., Hu, F. B., David, R. M., van Dam, R. M., Bralley, A., \& Williams, M. A. (2008). Maternal plasma 25-hydroxyvitamin D concentrations and the risk for 
gestational diabetes mellitus. PLoS One, 3(11), e3753. https://doi.org/10.1371/ journal.pone.0003753 PMID:19015731

Zhang, M. X., Pan, G. T., Guo, J. F., Li, B. Y., Qin, L. Q., \& Zhang, Z. L. (2015). Vitamin D Deficiency Increases the Risk of Gestational Diabetes Mellitus: A Meta-Analysis of Observational Studies. Nutrients, 7(10), 8366-8375. https://doi.org/10.3390/ nu7105398 PMID:26437429

Zhou, J., Su, L., Liu, M., Liu, Y., Cao, X., Wang, Z., \& Xiao, H. (2014). Associations between 25-hydroxyvitamin $D$ levels and pregnancy outcomes: A prospective observational study in southern China. European Journal of Clinical Nutrition, 68(8), 925-930. https:// doi.org/10.1038/ejcn.2014.99 PMID:24865483

Zuhur, S. S., Erol, R. S., Kuzu, I., \& Altuntas, Y. (2013). The relationship between low maternal serum 25-hydroxyvitamin $D$ levels and gestational diabetes mellitus according to the severity of 25-hydroxyvitamin D deficiency. Clinics (São Paulo), 68(5), 658-664. https://doi.org/10.6061/clinics/2013(05)13 PMID:23778416 